\title{
EFFECT OF CONGESTION ON FUEL COST AND TRAVEL TIME COST ON MULTI-LANE HIGHWAYS IN INDIA
}

\author{
Madhu Errampalli ${ }^{1}$, Velmurugan Senathipathi ${ }^{2}$, Deepa Thamban ${ }^{3}$ \\ ${ }^{1}$ Transportation Planning Division, Central Road Research Institute, Mathura Road, New Delhi 110025, India \\ ${ }^{2}$ Traffic Engineering and Safety Division, Central Road Research Institute, Mathura Road, New Delhi \\ 110025, India \\ ${ }^{3}$ National Institute of Technology, Surathkal 575025, India
}

Received 11 July 2014; accepted 18 February 2015

\begin{abstract}
The vehicles normally move at their free speeds when it is least impeded due to traffic flow under lean traffic (free flow) conditions. As traffic flow increases, the vehicles cannot sustain their free speeds due to interactions from other vehicles in the traffic stream. In addition to that the vehicles that are operating in the congested traffic conditions will consume more fuel than those operating in steady state traffic conditions for the same average speed. This leads to increase in travel time and fuel consumption of the vehicles and thereby adding to total road user cost (RUC). On the contrary, fuel consumption is also high at very high speeds under free flow traffic flow conditions leading to increase RUC. Considering these scenarios, the travel time and fuel cost of the vehicle due to the congestion and free flow conditions (uncongested) has to be necessarily modelled in order to estimate realistic assessment of RUC on Indian highways. In the present study, the congestion cost relationships have been developed between Congestion Factor, a ratio of cost under congestion and steady state conditions and Volume-Capacity Ratio by considering various vehicle types plying on varying widths of multi-lane highways (four, six and eight lane divided carriageways) through the collection of exhaustive time related and fuel related data. Time related data was collected through questionnaire survey method whereas fuel consumption data was collected using advanced sophisticated fuel flow measuring equipment (V-Box). The developed equations have been successfully applied to demonstrate their applicability in terms of estimating realistic effect of congestion on time and fuel cost by considering a section on NH-2 in Delhi. The analysis shows that the congestion effect is more significant on fuel cost for heavy commercial vehicles whereas it is more prominent on time cost for passenger vehicles. However, the congestion effect on combined fuel and time cost is more significant on multi-axle trucks followed by cars, two wheelers and buses.
\end{abstract}

Keywords: fuel cost, travel time cost, congestion, Indian highways.

\section{Introduction}

Traffic congestion is recognised throughout the world as a growing problem. It is particularly important in Asian countries like India where many cities operate under severely congested traffic conditions on a daily basis due to heterogeneous traffic mix. Congestion is in fact the saturation of road network capacity due to regular or irregular

\footnotetext{
${ }^{1}$ Corresponding author: madhu.crri@nic.in
} 
reductions in service quality, exemplified by increased travel times, variation in travel times and interrupted travel. In general, traffic congestion has three principal effects on road users namely increase of travel time required for trips, Vehicle Operating Costs (VOC) and quantum of emissions from vehicles. There are thus strong economic arguments for ameliorating traffic congestion. When the vehicle is moving under congested conditions, it has to undergo many operations like acceleration, deceleration, gear changes, brake applications etc. Maneuvering on congested roads will also result in additional wear and tear of moving parts and tyres etc. of the vehicles. Hence, the VOC (fuel cost is the major component) under congested traffic conditions would be higher than those under steady state. Moreover, the travel time increases as the volume increases adding to the time cost. Therefore, the equations evolved to estimate fuel and time cost under steady state will yield to unrealistic values. In spite of the fact that the fuel and time cost plays major role in road user costs, there has been relatively little research conducted into quantifying the effects of congestion on these components. By measuring the extra fuel and time consumed under congested conditions, the influence of congestion on these components can be quantified. In India, this was attempted for the first time in the study on Updating of Road User Cost Data (Kadiyali, 1992) and subsequently road user costs were further updated (CRRI, 2001; IRC, 2009). These studies covered up to fourlane divided carriageways only and moreover, the outcome of the above studies has become rather obsolete as the vehicle technology, roadway capacity augmentation and price has changed road scenario quite drastically in the recent times. In view of these issues, the formulated objectives of the study are as listed below:
- To develop fuel consumption equations for congested traffic conditions;

- To estimate the travel time cost under varying flow conditions;

- To develop congestion cost equations for fuel and time cost for different vehicle types considering varying widths of multi-lane divided carriageways.

In view of the above postulated objectives, a critical review of the congestion cost studies conducted at different parts of the world has been summarised in Section 2. In Section 3, the study methodology and data collection has been described. Development of fuel consumption equations under steady state and congested state is discussed in Section 4 whereas travel time cost equation development is given in Section 5. The final congestion cost equations developed are presented in Section 6. The effect of congestion on fuel and time cost considering a real test section of NH-2 in Delhi, India is discussed in Section 7 and finally, conclusions drawn from the study is given in Section 8.

\section{Review of Congestion Cost Studies}

As mentioned in previous section, congestion study was first time carried out in India as a part of Updating of Road User Cost Study Data in the year 1992 and subsequently updated in 2001 (Kadiyali, 1992; CRRI, 2001). The study conducted in 2001 has yielded updated relationships for time related and distance related congestion factor equations representing time and fuel cost respectively. There have only been some isolated attempts in Canada to measure the cost of congestion in specific urban areas which included three main components: delay costs (time wasted under congested conditions), vehicle operational cost (fuel wasted) and an imputed cost for excessive 
pollution cost due to traffic congestion for passenger vehicles, trucks and city buses (Transport Canada, 2006). The assessment of congestion costs in this study is mainly based on the estimated amount of time loss of road users due to congested traffic conditions corresponding to HCM levelsof-service D, E or F. Congestion study conducted in Australia dealt with the eight Australian capital cities by comparing the business as usual scenario with the horizon year projections in 2020 by assessing the social costs of congestion for the various Australian metropolitan traffic (BTRE, 2007). The congestion study conducted in London was aimed at the estimation of economic cost of congestion. It was inferred from this study that at very low levels of traffic volume, called 'free flow', changes in the number of vehicles would have little effect. But as traffic volume increases, even very small increases or reductions in traffic would have a disproportionately large effect on speed (Goodwin, 2004). The approach adopted in the Auckland study was based on modelling of acceleration noise defined as the standard deviation of the accelerations (Greenwood, 2003). During periods of high traffic congestion there is a greater variability in speed resulting in higher acceleration noise levels. Once the acceleration noise level is estimated, the impact on fuel consumption and vehicle emissions was determined. The US study on congestion cost evaluation emphasized accounting for the additional costs incurred due to unreliability as well as loss of mobility and excess emission costs in addition to the direct costs, including loss of time and excess fuel costs accrued to vehicle users (USDOT, 2009). Eventually, the principal categories of congestion cost considered in this study are travel time cost, unreliability cost, VOC, mobility cost and emission cost. Considering the above reviewed literature, the methodology has been devised as given in next section for accomplishing the envisaged objectives.

\section{Study Methodology and Data Collection}

\subsection{Methodology Adopted}

In order to achieve the objectives outlined above, adopted methodology for developing congestion cost equations considering fuel and time costs is shown in Fig. 1.

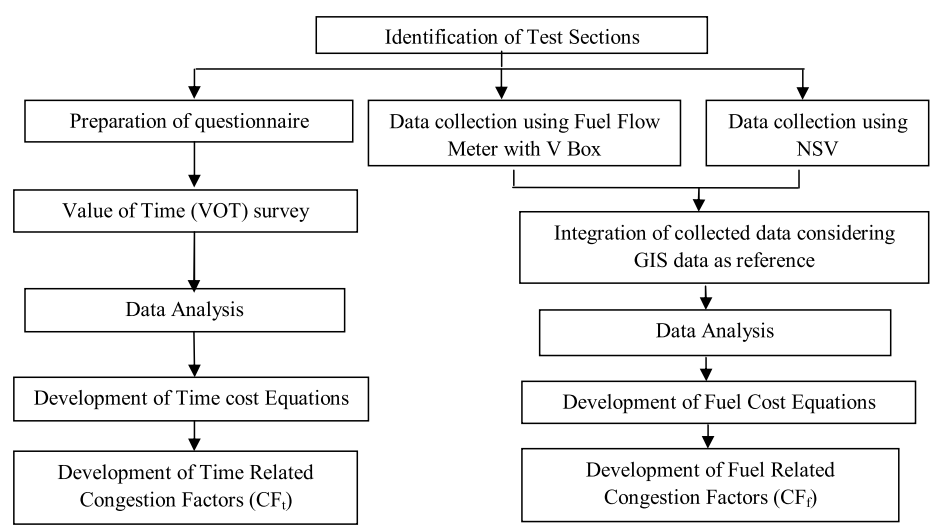

Fig. 1.

Flow Chart Illustrating Study Methodology 
As can be seen from the Fig. 1, identification of test sections have been done at the first instance to collect data related to fuel consumption and value of time data for different types of vehicles plying on multilane highways. The travel time data was collected using appropriately designed questionnaire whereas fuel consumption data has been collected using instrumented vehicle fitted with V-BOX and fuel flow meter. For the purpose of collecting road geometry data such as road roughness, rise and fall, network survey vehicle (NSV) has been used. By analyzing the Value of Time (VOT) data, travel time cost relationships are developed. Subsequently the speed - flow data analysed in another study (Velmurugan et al., 2010) has been used to develop time related congestion cost $\left(C_{t}\right)$ equations considering volume capacity ratio (V/C) as independent variable. Similarly, fuel consumption equations under congested state are developed using speed, road roughness, rise and fall as independent variables. Adopting steady state fuel consumption equations (Kumar, 2011), congestion factors for fuel cost are evolved and same procedure as time related congestion cost equations has been followed to develop fuel related congestion cost $\left(\mathrm{CF}_{f}\right)$ equations. The details of VOT and fuel consumption experiments under congested conditions are presented in the succeeding sections. The vehicle types considered in the present study include two wheeler ( $\mathrm{TW}$ ), small car (cars up to 1400 cc classified as SC), big car (cars beyond $1400 \mathrm{cc}$ classified as BC) and Two Axle Heavy Commercial Vehicles (HCV) for fuel consumptions experiments whereas buses, Light Commercial Vehicles (LCV), MultiAxle Heavy Commercial Vehicles (MCV) are also considered for time cost study. The auto rickshaws are not considered for this analysis due to the paucity of time and resources.

\subsection{VOT Data Collection}

For the development of the travel time cost models, the data was collected through VOT survey from the commuters of buses, private vehicles (i.e. cars and two wheelers) and goods vehicles separately through specially designed questionnaire on the selected multi-lane road corridors. The travel time cost for passenger vehicles is obtained by multiplying the travel time per $\mathrm{km}$ with the VOT of passengers and average occupancy of the vehicle. Mathematically it can be represented as Eq. (1):

$\mathrm{PTTC}_{i h}=T_{i h}^{*} \mathrm{O}_{i}^{*} \mathrm{VOT}_{i}$

Where, $P$ TTC = Passenger Travel Time Cost in Rs/Veh-km

$\mathrm{T}=$ Average Travel Time in $\mathrm{min} / \mathrm{km}$;

$\mathrm{O}=$ Occupancy

VOT = Value of Travel Time of the passengers in Rs/min

Subscripts ' $i$ ' and ' $h$ ' represents vehicle type and traffic flow respectively

The travel time cost for goods vehicles is obtained by multiplying the travel time per $\mathrm{km}$ with the Commodity Holding Cost (CHC) of the vehicle which is basically determined from the value of goods in transit (CRRI, 2001) obtained from Value of Commodity Surveys. Mathematically it can be written as Eq. (2):

$\mathrm{GTTC}_{i h}=\mathrm{T}_{i h}{ }^{*} \mathrm{CHC}_{i}$

Where, GTTC = Goods Travel Time Cost in Rs/Veh-km

$\mathrm{CHC}_{i}=$ Commodity Holding Cost in Rs/ $\min$

A total of 7861 samples are collected through VOT and Commodity surveys and the 
details of test sections considered for these the sample size on each corridor is presented surveys coupled with extent of coverage of in Table 1.

Table 1

Collected Data in Value of Time and Value of Commodity Surveys

\begin{tabular}{|c|c|c|c|c|}
\hline $\begin{array}{c}\text { Name of the National Highway (NH) } \\
\text { Test Section }\end{array}$ & Buses & $\begin{array}{c}\text { Private } \\
\text { Vehicles* }^{*}\end{array}$ & $\begin{array}{c}\text { Goods } \\
\text { Vehicles }\end{array}$ & Total \\
\hline Vijayawada-Eluru (NH-5) & 225 & 429 & 422 & 1076 \\
\hline Vijayawada-Guntur (NH-5) & 211 & 420 & 419 & 1050 \\
\hline Hyderabad-Bangalore (NH-7) & 204 & 255 & 339 & 798 \\
\hline Hyderabad-Nagpur (NH-7) & 128 & 354 & 400 & 882 \\
\hline Hyderabad-Mumbai (NH-9) & 214 & 412 & 372 & 998 \\
\hline Hyderabad-Vijayawada (NH-9) & 174 & 425 & 421 & 1020 \\
\hline Hyderabad-Warangal (NH-202) & 215 & 326 & 397 & 938 \\
\hline Sion-Panvel Highway & - & 424 & 300 & 724 \\
\hline Mumbra Bypass (NH-4) & - & - & 375 & 375 \\
\hline Total & 1371 & 3045 & 3445 & 7861 \\
\hline
\end{tabular}

Note: ${ }^{*}$ Private Vehicles include Cars and Motorised Two Wheelers (TW), ** Goods Vehicles include Light Commercial Vehicles (LCV), Two Axle Heavy Commercial Vehicle (HCV) and Multi-Axle Commercial Vehicle $(\mathrm{MCV})$

\subsection{Congested State Fuel Consumption Data}

As mentioned earlier, unlike in the previous Indian studies, the fuel consumption data under congested traffic conditions has been collected in a novel fashion by using instrumented vehicle fitted with the sophisticated Fuel Flow Meter and V-Box instrumentation system whereas road geometric data has been measured using the NSV. As indicated earlier, the fuel data was collected on $\mathrm{NH}-1$ in the case of $\mathrm{HCV}$ whereas on Delhi - Gurgaon Expressway in the case of petrol and diesel driven cars. At the same time, vehicle owner's evaluation on the quantum of fuel consumed for the entire length of their commute collected on the study sections listed in Table 1 was utilized appropriately in the case of TW to derive the congested state fuel consumption equations.

\section{Development of Fuel Consumption Equations}

Fuel consumption of the vehicles are highly dependent on the vehicles operating speed and also the road geometry characteristics namely roughness, rise and fall etc. The pay load also influences fuel consumption in case of commercial vehicles. As per the methodology explained in previous section, fuel consumption data has been collected using V-Box under congested state conditions. Apart from the fuel and speed data collection, road geometry namely roughness, rise and fall also collected on the same test sections. Fuel consumption 
equations under steady state developed in another study (Kumar, 2011) with influencing variables of speed, roughness, rise and fall. Then congested state fuel consumption equations are formulated as a function of steady state fuel consumption and speed. The developed fuel consumption equations under steady and congested state for different vehicle types are described in subsequent sections.

\subsection{Steady State Fuel Consumption Equations}

From the collected data, the fuel consumption equation for petrol driven small cars (SC), diesel driven big cars (BC) and $\mathrm{HCV}$ evolved under steady state conditions (Kumar, 2011) is as given below:

$$
\begin{aligned}
& F C_{S C}{ }^{S T}=30+844.085 / V_{S C}+0.003^{*} V_{S C}{ }^{2}+0.001^{*} R+0.4552^{*} R S-0.89^{*} F L \\
& F C_{B C}{ }^{S T}=35+983.503 / V_{B C}+0.003^{*} V_{B C}{ }^{2}+0.002^{*} R+0.452^{*} R S-1.914^{*} F L \\
& F C_{H C V}{ }^{S T}=50+8049.95 / V_{H C V}+0.012^{*} V_{H C V}{ }^{2}+0.005^{*} R+4.565^{*} R S-4.904^{*} F L-7.285^{*} P / W
\end{aligned}
$$

$$
\text { Where } \begin{array}{ll}
F C & =\text { Fuel consumption in } \mathrm{ml} / \mathrm{km} \\
V & =\text { Speed in } \mathrm{kmph} \\
R & =\text { Roughness in } \mathrm{mm} / \mathrm{km} \\
R S & =\text { Rise in } \mathrm{m} / \mathrm{km} \\
F L & =\text { Fall in } \mathrm{m} / \mathrm{km} \\
P / W & =\text { Power }- \text { Weight Ratio }
\end{array}
$$

Superscript ' $S T$ ' represents steady state condition

Subscript ' $S C$ ', ' $B C$ ' and ' $H C V$ ' represents Small Car, Big Car and Heavy Commercial Vehicle respectively

Since the data collection for HCV was carried out under varying load conditions namely empty, half and fully loaded, the variable $\mathrm{P} / \mathrm{W}$ has been introduced in the fuel consumption equation for HCV. The steady state fuel consumption equation of Two Wheelers (TW) as given in IRC:SP-30 (IRC, 2009) has been deployed which is given below:

$F C_{T W}{ }^{S T}=3.38+549.57 / V_{T W}+0.00436^{*} V_{T W}{ }^{2}+0.000196^{*} R+0.4552^{*} R S-0.3386^{*} F L$

Where Subscript ' $T W$ ' represents Motorised Two Wheelers.

\subsection{Congested State Fuel Consumption Equations}

In the present study, the congested fuel consumption is defined as a factor of steady state fuel consumption as given below:

$F C_{i}^{C O N}=f(V)^{*} F C_{i}{ }^{S T}$
Where $f(V)$ is a factor defined as the ratio of congested and steady state FC Superscript ' $C O N$ ' and ' $S T$ ' represents congested and steady state respectively Subscript ' $i$ ' represents vehicle type

Using the collected fuel consumption data under both steady and congested state 
condition and associated speed, equations for $f(V i)$ for different vehicle types have been

$f\left(V_{S C}\right)=0.0003 * V_{S C}{ }^{2}-0.0344 * V_{S C}+1.9555$

$f\left(V_{B C}\right)=0.0005 * V_{B C}{ }^{2}-0.0609 * V_{B C}+2.8175$

$f\left(V_{T W}\right)=0.0005 * V_{T W}{ }^{2}-0.0465 * V_{T W}+2.0556$

developed considering speed as influencing variable is given below:

$[\mathrm{R} 2=0.51]$

$[\mathrm{R} 2=0.44]$

$[\mathrm{R} 2=0.60]$

$f\left(V_{H C V}\right)=0.0017 * V_{H C V}{ }^{2}-0.2014 * V_{H C V}+7.0539$

$[\mathrm{R} 2=0.55]$

The comparison of steady state and congested state fuel consumptions under varying speeds are shown in the Fig. 2.
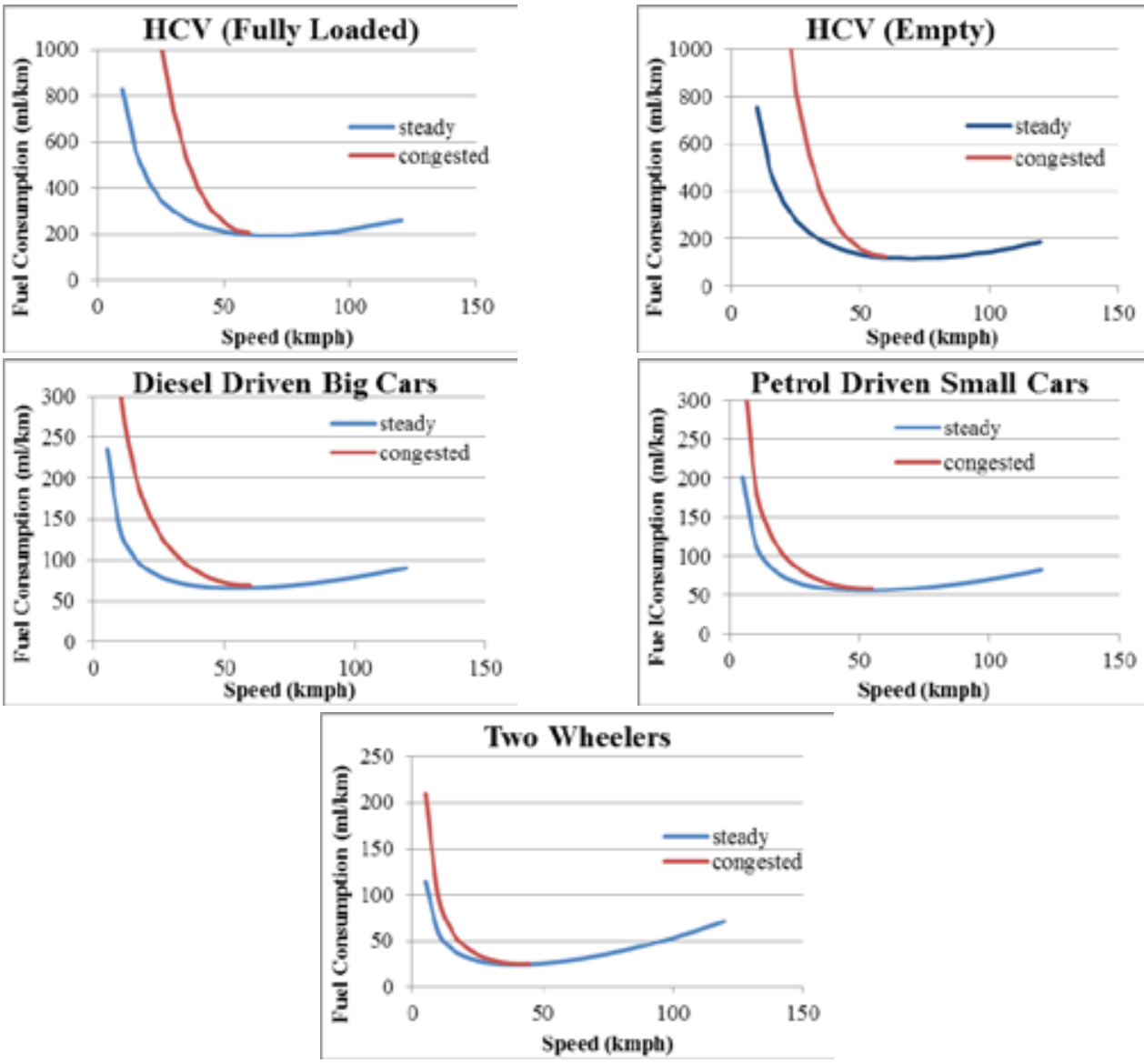

Fig. 2.

Comparison of Steady State and Congested State Fuel Consumption of Different Vehicle Types under Varying Speeds 
A close look at Fig. 2 reveals that as the speed increases, the rate of fuel consumption decreases till the vehicle reaches its optimum speed and further, it can be noted that the steady state and the congested state fuel consumption curves meet at a particular speed and beyond this speed, the fuel consumption gradually increases as the vehicle approaches free speed. Therefore, the fuel consumption under steady state will only be only valid beyond this optimum point and this merging point of steady and congested speed for SC, BC, TW and $\mathrm{HCV}$ are around $58,62,45$ and $60 \mathrm{kmph}$ respectively. It can also be further noted from Fig. 2 that the change in quantum of fuel consumption of TW under congested and steady state is quite negligible and hence both curves meet around $45 \mathrm{kmph}$. This phenomenon may be attributed to the fact that two wheeler drivers tend to negotiate zigzag manner under congested traffic situation on Indian roads and hence the fuel loss is minimum.

\section{Development of Travel Time Cost Equations}

The basic outcome of congestion due to increase in traffic volume is the increase in travel time of the passengers. If one considers the total transportation cost, the time costs are considerably larger in portion of the VOC and hence added importance is to be attributed to this element in the analysis of congestion cost. In the present study, the travel time cost for passengers' vehicles is obtained by multiplying the travel time per $\mathrm{km}$ with the value of time of passengers and average occupancy of vehicle. The travel time per $\mathrm{km}$ for different vehicle types for varying flows were arrived from VOT study. Based on the average occupancy of vehicles observed during the survey presented in the earlier section, Travel Time Cost (TTC) equations as a function of traffic flow for different road types namely four-lane, six-lane and eight-lane divided carriageways have been developed. Similarly, the TTC for goods vehicles has been determined by multiplying the travel time per $\mathrm{km}$ with the $\mathrm{CHC}$ of the vehicle. Speed - Flow studies conducted on the identified test sections listed in earlier section has been utilized for the estimation of the TTC. Based on the same, the relationship between TTC and traffic flow (V) for different goods vehicle types has been established as presented in Table 2 for different carriageway types.

From Table 2, it can be observed that as the traffic flow increases, travel time cost increases as the coefficient in the equation is always positive for all vehicle and carriageway types. Further, it is evident from the above equations that the increase in traffic flow largely affects the private vehicles and buses as compared to the commercial vehicles. Having developed the above described fuel and travel time cost equations, these are eventually deployed for formulating the congestion cost equations. 
Table 2

Travel Time Cost Equations for Different Vehicle Types on Different Carriageways

\begin{tabular}{|c|c|c|c|c|c|c|}
\hline $\begin{array}{c}\text { Carria- } \\
\text { geway } \\
\text { Type }\end{array}$ & Cars & TW & Buses & LCVs & HCVs & MCVs \\
\hline Four Lane & $\begin{array}{l}\mathrm{TTC}= \\
0.0012^{*} \mathrm{~V}+ \\
5.7735 \\
\left(\mathrm{R}^{2}=0.85\right) \\
10.22,28.21 @ \\
0.000,0.205 \#\end{array}$ & $\begin{array}{l}\mathrm{TTC}= \\
0.0003^{*} \mathrm{~V}+ \\
0.7378 \\
\left(\mathrm{R}^{2}=0.96\right) \\
13.50,13.13 @ \\
0.000,0.056 \#\end{array}$ & $\begin{array}{l}\mathrm{TTC}= \\
0.008^{*} \mathrm{~V}+ \\
24.15 \\
\left(\mathrm{R}^{2}=0.89\right) \\
11.02,15.90 @ \\
0.001,1.520 \#\end{array}$ & $\begin{array}{l}\mathrm{TTC}= \\
0.00003^{*} \mathrm{~V}+ \\
0.0973 \\
\left(\mathrm{R}^{2}=0.78\right) \\
7.42,13.98 @ \\
0.000,0.007 \text { }\end{array}$ & $\begin{array}{l}\mathrm{TTC}= \\
0.00004^{*} \mathrm{~V}+ \\
0.1734 \\
\left(\mathrm{R}^{2}=0.74\right) \\
6.45,14.53 @ \\
0.000,0.012 \#\end{array}$ & $\begin{array}{l}\mathrm{TTC}= \\
0.00007^{*} \mathrm{~V}+ \\
0.2561 \\
\left(\mathrm{R}^{2}=0.64\right) \\
4.983,9.481 @ \\
0.000,0.027 \#\end{array}$ \\
\hline Six Lane & $\begin{array}{l}\mathrm{TTC}= \\
0.0011^{*} \mathrm{~V}+ \\
4.9301 \\
\left(\mathrm{R}^{2}=0.47\right) \\
2.971,5.245 @ \\
0.000,0.940 \#\end{array}$ & $\begin{array}{l}\mathrm{TTC}= \\
0.0002^{*} \mathrm{~V}+ \\
0.8901 \\
\left(\mathrm{R}^{2}=0.66\right) \\
5.399,8.944 @ \\
0.000,0.100 \#\end{array}$ & $\begin{array}{l}\mathrm{TTC}= \\
0.003^{*} \mathrm{~V}+ \\
27.67 \\
\left(\mathrm{R}^{2}=0.69\right) \\
5.035 \\
16.097 @ \\
0.001,1.719 \#\end{array}$ & $\begin{array}{l}\mathrm{TTC}= \\
0.000001^{*} \mathrm{~V}+ \\
0.0827 \\
\left(\mathrm{R}^{2}=0.65\right) \\
2.560,12.98 @ \\
0.000,0.006 \#\end{array}$ & $\begin{array}{l}\mathrm{TTC}= \\
0.00004^{*} \mathrm{~V}+ \\
0.1232 \\
\left(\mathrm{R}^{2}=0.71\right) \\
6.871,9.566 @ \\
0.000,0.013 \#\end{array}$ & $\begin{array}{l}\mathrm{TTC}= \\
0.00008^{*} \mathrm{~V}+ \\
0.2072 \\
\left(\mathrm{R}^{2}=0.57\right) \\
0.962,3.558 @ \\
0.000,0.068 \#\end{array}$ \\
\hline Eight Lane & $\begin{array}{l}\mathrm{TTC}= \\
0.0004^{*} \mathrm{~V}+ \\
6.7308 \\
\left(\mathrm{R}^{2}=0.86\right) \\
12.862, \\
36.28 @ \\
0.000,0.186 \#\end{array}$ & $\begin{array}{l}\mathrm{TTC}= \\
0.0001^{*} \mathrm{~V}+ \\
0.798 \\
\left(\mathrm{R}^{2}=0.82\right) \\
7.514,12.67 @ \\
0.000,0.063 \#\end{array}$ & $\begin{array}{l}\mathrm{TTC}= \\
0.001^{*} \mathrm{~V}+ \\
35.69 \\
\left(\mathrm{R}^{2}=0.84\right) \\
12.533 \\
45.71 @ \\
0.000,0.781 \#\end{array}$ & $\begin{array}{l}\mathrm{TTC}= \\
0.00001^{*} \mathrm{~V}+ \\
0.1148 \\
\left(\mathrm{R}^{2}=0.78\right) \\
8.261,29.00 @ \\
0.000,0.004 \#\end{array}$ & $\begin{array}{l}\mathrm{TTC}= \\
0.00001^{*} \mathrm{~V}+ \\
0.1722 \\
\left(\mathrm{R}^{2}=0.53\right) \\
2.373,6.622 @ \\
0.000,0.026 \#\end{array}$ & $\begin{array}{l}\mathrm{TTC}= \\
0.00001^{*} \mathrm{~V}+ \\
0.3182 \\
\left(\mathrm{R}^{2}=0.61\right) \\
3.517 \\
15.564 @ \\
0.000,0.020 \#\end{array}$ \\
\hline
\end{tabular}

Note: TTC-Travel Time Cost; V-Volume (Traffic Flow) in Passenger Car Units (PCU)/hr (a) represents the calculated $t$-value of coefficients and constant respectively \# represents the standard error of the coefficients and constant respectively

\section{Congestion Cost Equations}

Fuel consumption has been estimated under congested condition for each type of vehicle and road type. The ratio of the fuel consumption under congested state with steady state is termed as Fuel Related Congestion Factor $\left(\mathrm{CF}_{f}\right)$ has been estimated. These estimated factors are used to develop the fuel related congestion cost equations considering Volume Capacity Ratio (V/C) as influencing variable. Since the fuel consumption increases at both lower speeds and higher speeds compared to optimum speed, the fuel consumption for different vehicle types on different carriageway types are estimated both under uncongested area and congested area of vehicle maneuvers respectively. The former one is termed as fuel consumption due to high speeds/ free flow speeds (uncongested) whereas the latter one is termed as fuel consumption due to congestion. The ratio between fuel consumption due to congestion and steady state fuel consumption is called Congestion Factor (CF) whereas the ratio between fuel consumption due to free flow speeds (uncongested) and steady state fuel consumption is called freeflow or uncongested factor (UCF). The relationship between these factors and V/C ratios for these conditions are separately determined for each of the vehicle types on varying widths of multi-lane highways. The summary of the fuel related congestion cost equations developed in this study following the above analogy are presented in Table 3 for different vehicle types covering varying 
widths of multi-lane highways. The travel time cost observed was compared with the acceptable travel time cost (under free-flow conditions) and the ratio of the observed and acceptable travel time cost which is termed as Time Related Congestion Factor $\left(\mathrm{CF}_{t}\right)$ was determined for different vehicles on varying road widths. Finally, statistical relationships were developed between $\mathrm{CF}_{t}$ and $\mathrm{V} / \mathrm{C}$ ratio and they are also presented in Table 4 for different vehicle types considering four-lane, six lane and eight lane divided carriageways respectively. It can be inferred from Table 3 that the time cost under free speed condition will be the minimum travel time cost that a person attains during his journey. Hence the congestion factor should be always greater than one, which is clearly observed in Table 4. Further it can be inferred based on the estimated statistical parameters; the developed fuel related congestion cost equations exhibit good statistical significance.

\section{Table 3}

Fuel Related Congestion Cost Equations for Different Vehicle Types on Different Carriageways

\begin{tabular}{|c|c|c|c|c|c|c|}
\hline \multirow{2}{*}{$\begin{array}{c}\text { Vehicle } \\
\text { Type }\end{array}$} & \multicolumn{2}{|c|}{$\begin{array}{c}\text { Four Lane Divided } \\
\text { Carriageways }\end{array}$} & \multicolumn{2}{|c|}{$\begin{array}{c}\text { Six Lane Divided } \\
\text { Carriageways }\end{array}$} & \multicolumn{2}{|c|}{$\begin{array}{l}\text { Eight Lane Divided } \\
\text { Carriageways }\end{array}$} \\
\hline & $\begin{array}{c}\text { Uncongested } \\
\text { Area }\end{array}$ & $\begin{array}{c}\text { Congested } \\
\text { Area }\end{array}$ & $\begin{array}{c}\text { Uncongested } \\
\text { Area }\end{array}$ & $\begin{array}{c}\text { Congested } \\
\text { Area }\end{array}$ & $\begin{array}{c}\text { Uncongested } \\
\text { Area }\end{array}$ & $\begin{array}{c}\text { Congested } \\
\text { Area }\end{array}$ \\
\hline SC & $\begin{array}{l}\mathrm{UCFF}= \\
2.4405^{*}(\mathrm{~V} / \mathrm{C})^{2} \\
-2.8919^{*}(\mathrm{~V} / \mathrm{C}) \\
+1.8939 \\
\mathrm{R}^{2}=0.89\end{array}$ & $\begin{array}{l}\mathrm{CFF}= \\
0.3748^{*}(\mathrm{~V} / \mathrm{C})^{2} \\
-0.7025^{*}(\mathrm{~V} / \mathrm{C}) \\
+1.4491 \\
\mathrm{R}^{2}=0.84\end{array}$ & $\begin{array}{l}\mathrm{UCFF}= \\
2.8163^{*}(\mathrm{~V} / \mathrm{C})^{2} \\
-3.1278^{*}(\mathrm{~V} / \mathrm{C}) \\
+1.9629 \\
\mathrm{R}^{2}=0.62\end{array}$ & $\begin{array}{l}\mathrm{CFF}= \\
1.4596^{*}(\mathrm{~V} / \mathrm{C})^{2} \\
-1.7241^{*}(\mathrm{~V} / \mathrm{C}) \\
+1.7216 \\
\mathrm{R}^{2}=0.67\end{array}$ & $\begin{array}{l}\mathrm{UCFF}= \\
0.5239^{*}(\mathrm{~V} / \mathrm{C})^{2} \\
-0.9289^{*}(\mathrm{~V} / \mathrm{C}) \\
+1.4847 \\
\mathrm{R}^{2}=0.90\end{array}$ & $\begin{array}{l}\mathrm{CFF}= \\
0.1728^{*}(\mathrm{~V} / \mathrm{C})^{2} \\
-0.3638^{*}(\mathrm{~V} / \mathrm{C}) \\
+1.255 \\
\mathrm{R}^{2}=0.38\end{array}$ \\
\hline BC & $\begin{array}{l}\mathrm{UCFF}= \\
3.713^{*}(\mathrm{~V} / \mathrm{C})^{2}- \\
4.2811^{*}(\mathrm{~V} / \mathrm{C}) \\
+2.2173 \\
\mathrm{R}^{2}=0.88\end{array}$ & $\begin{array}{l}\mathrm{CFF}= \\
0.6806^{*}(\mathrm{~V} / \mathrm{C})^{2}- \\
1.3196^{*}(\mathrm{~V} / \mathrm{C}) \\
+1.8488 \\
\mathrm{R}^{2}=0.85\end{array}$ & $\begin{array}{l}\mathrm{UCFF}= \\
4.3108^{*}(\mathrm{~V} / \mathrm{C})^{2}- \\
4.6276^{*}(\mathrm{~V} / \mathrm{C}) \\
+2.3129 \\
\mathrm{R}^{2}=0.62\end{array}$ & $\begin{array}{l}\mathrm{CFF}= \\
2.6726^{*}(\mathrm{~V} / \mathrm{C})^{2}- \\
3.1988^{*}(\mathrm{~V} / \mathrm{C}) \\
+2.3539 \\
\mathrm{R}^{2}=0.68\end{array}$ & $\begin{array}{l}\mathrm{UCFF}= \\
0.7734^{*}(\mathrm{~V} / \mathrm{C})^{2}- \\
1.3037^{*}(\mathrm{~V} / \mathrm{C}) \\
+1.596 \\
\mathrm{R}^{2}=0.90\end{array}$ & $\begin{array}{l}\mathrm{CFF}= \\
0.3433^{*}(\mathrm{~V} / \mathrm{C})^{2} \\
-0.7549^{*}(\mathrm{~V} / \mathrm{C}) \\
+1.4877 \\
\mathrm{R}^{2}=0.42\end{array}$ \\
\hline TW & $\begin{array}{l}\mathrm{UCFF}= \\
4.9774^{*}(\mathrm{~V} / \mathrm{C})^{2} \\
-4.8846^{*}(\mathrm{~V} / \mathrm{C}) \\
+2.1831 \\
\mathrm{R}^{2}=0.98\end{array}$ & $\begin{array}{l}\mathrm{CFF}= \\
3.6407^{*}(\mathrm{~V} / \mathrm{C})^{2} \\
-2.1999^{*}(\mathrm{~V} / \mathrm{C}) \\
+1.437 \\
\mathrm{R}^{2}=0.84\end{array}$ & $\begin{array}{l}\mathrm{UCFF}= \\
5.6528^{*}(\mathrm{~V} / \mathrm{C})^{2} \\
-4.5691^{*}(\mathrm{~V} / \mathrm{C}) \\
+1.9083 \\
\mathrm{R}^{2}=0.75\end{array}$ & $\begin{array}{l}\mathrm{CFF}= \\
5.1874^{*}(\mathrm{~V} / \mathrm{C})^{2} \\
-4.4089^{*}(\mathrm{~V} / \mathrm{C}) \\
+2 \\
\mathrm{R}^{2}=0.75\end{array}$ & $\begin{array}{l}\mathrm{UCFF}= \\
2.4879^{*}(\mathrm{~V} / \mathrm{C})^{2} \\
-3.9095^{*}(\mathrm{~V} / \mathrm{C}) \\
+2.6253 \\
\mathrm{R}^{2}=0.96\end{array}$ & $\begin{array}{l}\mathrm{CFF}= \\
0.0962^{*}(\mathrm{~V} / \mathrm{C})^{2} \\
-0.1749^{*}(\mathrm{~V} / \mathrm{C}) \\
+1.0998 \\
\mathrm{R}^{2}=0.42\end{array}$ \\
\hline $\mathrm{HCV}$ & $\begin{array}{l}\mathrm{UCFF}= \\
2.8147^{*}(\mathrm{~V} / \mathrm{C})^{2}- \\
1.5589^{*}(\mathrm{~V} / \mathrm{C}) \\
+1.4185 \\
\mathrm{R}^{2}=0.57\end{array}$ & $\begin{array}{l}\mathrm{CFF}= \\
0.2295^{*}(\mathrm{~V} / \mathrm{C})^{2} \\
-2.6177^{*}(\mathrm{~V} / \mathrm{C}) \\
+3.1499 \\
\mathrm{R}^{2}=0.98\end{array}$ & $\begin{array}{l}\mathrm{UCFF}= \\
18.737^{*}(\mathrm{~V} / \mathrm{C})^{2} \\
-15.017^{*}(\mathrm{~V} / \mathrm{C}) \\
+4.0302 \\
\mathrm{R}^{2}=0.54\end{array}$ & $\begin{array}{l}\mathrm{CFF}= \\
17.503^{*}(\mathrm{~V} / \mathrm{C})^{2} \\
-16.373^{*}(\mathrm{~V} / \mathrm{C}) \\
+6.0868 \\
\mathrm{R}^{2}=0.63\end{array}$ & $\begin{array}{l}\mathrm{UCFF}= \\
0.9634^{*}(\mathrm{~V} / \mathrm{C})^{2} \\
-0.9018^{*}(\mathrm{~V} / \mathrm{C}) \\
+1.279 \\
\mathrm{R}^{2}=0.18\end{array}$ & $\begin{array}{l}\mathrm{CFF}= \\
0.5461^{*}(\mathrm{~V} / \mathrm{C})^{2} \\
-1.7695^{*}(\mathrm{~V} / \mathrm{C}) \\
+2.5345 \\
\mathrm{R}^{2}=0.66\end{array}$ \\
\hline
\end{tabular}


Table 4

Time Related Congestion Cost Equations for Different Vehicle Types on Different Carriageways

\begin{tabular}{|l|l|l|l|}
\hline $\begin{array}{c}\text { Vehicle } \\
\text { Type }\end{array}$ & \multicolumn{1}{|c|}{$\begin{array}{c}\text { Four Lane Divided } \\
\text { Carriageways }\end{array}$} & \multicolumn{1}{c}{$\begin{array}{c}\text { Six Lane Divided } \\
\text { Carriageways }\end{array}$} & \multicolumn{1}{c|}{$\begin{array}{c}\text { Eight Lane Divided } \\
\text { Carriageways }\end{array}$} \\
\hline Cars & $\begin{array}{l}\mathrm{CFt}=0.4834^{*}(\mathrm{~V} / \mathrm{C}) 2+ \\
0.4095^{*}(\mathrm{~V} / \mathrm{C})+0.99 ; \mathrm{R}^{2}=0.78\end{array}$ & $\begin{array}{l}\mathrm{CFt}=2.1947^{*}(\mathrm{~V} / \mathrm{C}) 2- \\
0.3352^{*}(\mathrm{~V} / \mathrm{C})+1 ; \mathrm{R}^{2}=0.57\end{array}$ & $\begin{array}{l}\mathrm{CFt}=-.2441^{*}(\mathrm{~V} / \mathrm{C}) 2+ \\
0.9003^{*}(\mathrm{~V} / \mathrm{C})+0.99 ; \mathrm{R}^{2}=0.87\end{array}$ \\
\hline TW & $\begin{array}{l}\mathrm{CFt}=1.1063^{*}(\mathrm{~V} / \mathrm{C})+0.99 \\
\mathrm{R}^{2}=0.82\end{array}$ & $\begin{array}{l}\mathrm{CFt}=0.8998^{*}(\mathrm{~V} / \mathrm{C}) 2+ \\
0.9407^{*}(\mathrm{~V} / \mathrm{C})+1 ; \mathrm{R}^{2}=0.62\end{array}$ & $\begin{array}{l}\mathrm{CF}=0.3973^{*}(\mathrm{~V} / \mathrm{C})+1 \\
\mathrm{R}^{2}=0.75\end{array}$ \\
\hline Buses & $\begin{array}{l}\mathrm{CFt}=1.534^{*}(\mathrm{~V} / \mathrm{C}) 2- \\
0.2301^{*}(\mathrm{~V} / \mathrm{C})+0.99 ; \mathrm{R}^{2}=0.87\end{array}$ & $\begin{array}{l}\mathrm{CFt}=0.9412^{*}(\mathrm{~V} / \mathrm{C}) 2- \\
0.1881^{*}(\mathrm{~V} / \mathrm{C})+1 ; \mathrm{R}^{2}=0.60\end{array}$ & $\begin{array}{l}\mathrm{CFt}=-0.0092^{*}(\mathrm{~V} / \mathrm{C}) 2+ \\
0.4559^{*}(\mathrm{~V} / \mathrm{C})+1 ; \mathrm{R}^{2}=0.84\end{array}$ \\
\hline $\mathbf{M C V}$ & $\begin{array}{l}\mathrm{CFt}=0.8441^{*}(\mathrm{~V} / \mathrm{C}) 2+ \\
0.4337^{*}(\mathrm{~V} / \mathrm{C})+0.99 ; \mathrm{R}^{2}=0.75\end{array}$ & $\begin{array}{l}\text { not covered in this study due to } \\
\text { inadequate sample size }\end{array}$ & $\begin{array}{l}\mathrm{CFt}=-0.1476^{*}(\mathrm{~V} / \mathrm{C}) 2+ \\
0.5986^{*}(\mathrm{~V} / \mathrm{C})+0.99 ; \mathrm{R}^{2}=0.80\end{array}$ \\
\hline $\mathbf{H C V}$ & $\begin{array}{l}\mathrm{CFt}=1.1036^{*}(\mathrm{~V} / \mathrm{C}) 2+ \\
0.4124^{*}(\mathrm{~V} / \mathrm{C})+0.99 ; \mathrm{R}^{2}=0.80\end{array}$ & $\begin{array}{l}\mathrm{CFt}=1.593^{*}(\mathrm{~V} / \mathrm{C}) 2- \\
0.0523^{*}(\mathrm{~V} / \mathrm{C})+1 ; \mathrm{R}^{2}=0.72\end{array}$ & $\begin{array}{l}\mathrm{CFt}=0.2143^{*}(\mathrm{~V} / \mathrm{C}) 2+ \\
0.457^{*}(\mathrm{~V} / \mathrm{C})+1 ; \mathrm{R}^{2}=0.53\end{array}$ \\
\hline
\end{tabular}

\section{Effect of Congestion on Fuel and Time}

\section{Cost}

To demonstrate the suitability of the congestion cost equations developed in this study, $1 \mathrm{~km}$ test stretch of Ashram Badarpur Border section of NH-2 in Delhi, India has been considered. This is a six-lane divided carriageway located on plain terrain conditions and possessing a roughness of $2000 \mathrm{~mm} / \mathrm{km}$. The observed 16 hour traffic flow on this road section based on the recent study conducted by CRRI in 2009 (Deepa, 2011) has been used to work out the impact of congestion. The traffic flow pattern and composition of the traffic is shown in Fig. 3. From Fig. 3, it can be seen peak hour is occurring around 9:00 $A M$ with about 11000 vehicles/hour. The major share of the vehicles are cars about $45 \%$ followed by two wheelers about $31 \%$. The fuel consumption and time cost has been estimated for the observed classified traffic flow from 6:00 AM to 10:00 PM. Using the equations evolved in this study and assuming the prevailing cost of petrol and diesel per liter in \$ (USD) as \$ 1.2 and $\$ 0.8$ respectively, the quantum of expenses on fuel and travel time cost of selected vehicle types under steady and congested traffic flow conditions on NH-2 has been determined and presented in Table 5 and Table 6. From these results, fuel and time cost per $\mathrm{km}$ is calculated and shown in Table 7 for different types of vehicles coupled with comparing the same with the steady state costs presented in IRC:SP-30 (IRC, 2009). 


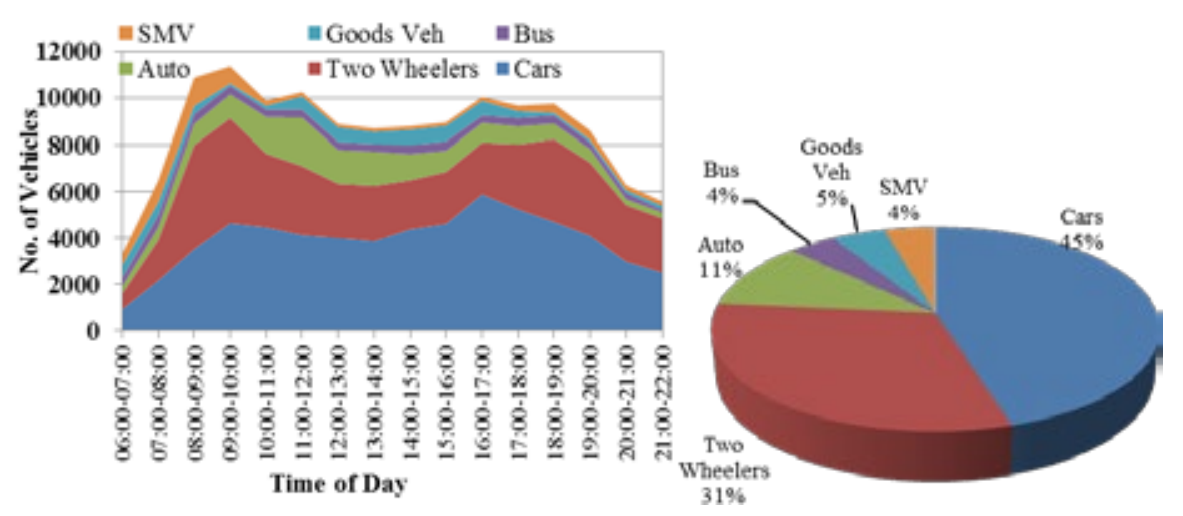

Note: Goods Vehicles include LCV, HCV and MCV

Fig. 3.

Hourly Traffic Volume and Composition on Ashram - Badarpur Section of NH-2

\section{Table 5}

Estimated Total Fuel Cost of Selected Vehicles under Steady and Congested Traffic Flow Conditions on $\mathrm{NH}-2$ for $1 \mathrm{~km}$ Stretch

\begin{tabular}{|l|c|c|c|c|}
\hline $\begin{array}{c}\text { Vehicle } \\
\text { Type }\end{array}$ & $\begin{array}{c}\text { Total Fuel Cost Under } \\
\text { Steady State (in \$) }\end{array}$ & $\begin{array}{c}\text { Total Fuel Cost Under } \\
\text { Congested State (in \$) }\end{array}$ & $\begin{array}{c}\text { Percent } \\
\text { Change }\end{array}$ & Fuel Loss (\$) \\
\hline Petrol Car & 2966.82 & 3615.40 & 21.9 & 648.58 \\
\hline Diesel Car & 916.32 & 1267.14 & 38.3 & 350.82 \\
\hline TW & 1391.70 & 1694.02 & 21.7 & 302.32 \\
\hline HCV & 177.90 & 398.02 & 123.7 & 220.12 \\
\hline Buses & 718.40 & 1647.68 & 129.4 & 929.28 \\
\hline MCV & 86.22 & 203.28 & 135.8 & 117.06 \\
\hline Total & $\mathbf{6 2 5 7 . 3 6}$ & $\mathbf{8 8 2 5 . 5 4}$ & $\mathbf{4 1 . 0}$ & $\mathbf{2 5 6 8 . 1 8}$ \\
\hline
\end{tabular}

\section{Table 6}

Estimated Total Travel Time Cost of Selected Vehicles under Steady and Congested Traffic Flow Conditions on NH-2 for $1 \mathrm{~km}$ Stretch

\begin{tabular}{|l|c|c|c|c|}
\hline $\begin{array}{c}\text { Vehicle } \\
\text { Type }\end{array}$ & $\begin{array}{c}\text { Total Travel Time Cost } \\
\text { Under Steady State (in \$) }\end{array}$ & $\begin{array}{c}\text { Total Travel Time Cost Under } \\
\text { Congested State (in \$) }\end{array}$ & $\begin{array}{c}\text { Percent } \\
\text { Change }\end{array}$ & Time Loss (\$) \\
\hline Cars & 8352.04 & 12917.04 & 54.66 & 4565.00 \\
\hline TW & 457.36 & 836.62 & 82.92 & 758.52 \\
\hline HCV & 4.32 & 6.16 & 42.65 & 1.84 \\
\hline Buses & 3160.20 & 3750.08 & 18.67 & 589.88 \\
\hline LCV & 10.06 & 15.12 & 50.37 & 5.06 \\
\hline MCV & 3.08 & 4.70 & 52.70 & 1.62 \\
\hline Total & $\mathbf{1 1 9 8 7 . 0 6}$ & $\mathbf{1 7 5 2 9 . 7 2}$ & $\mathbf{4 7 . 5 9}$ & $\mathbf{5 9 2 1 . 9 2}$ \\
\hline
\end{tabular}


A close look at Tables 5, 6 and 7 reveals the following:

- The congestion is causing an extra fuel being burnt (about 41 percent) and time spent (about 48 percent) during the travel considering cars, two wheelers, HCV and MCV except Autos. This situation is leading to a huge economy loss of about \$ 2568 and \$ 5922 respectively in a day for one kilometer of stretch due to this extra fuel and time spent during the travel.

- It can be noted that amongst the passenger vehicles the impact of congestion is more profound on cars ranging from 22 percent to 38 percent in the case of fuel consumption related congestion effect whereas the time related congestion effect is estimated to be as high as 83 percent. This is quite logical as the time value attached by the private vehicle commuters is quite substantial and therefore during congestion, it is getting reflected.

- The impact of fuel consumption related congestion is very high (135 percent) in the case of MCV.

- The congestion effect is more significant in terms of fuel cost on heavy vehicles whereas it is more prominent in passenger vehicles in case of time cost. However, the congestion effect on combined fuel and time cost is more significant on MCV (133 percent) and HCV (119 percent) whereas it is about 45 percent for cars and two wheelers and about 35 percent for buses.

- The estimated fuel cost values are also in conformity with IRC: SP-30 (IRC, 2009) as the fuel price has registered drastic increase since 2009. The time cost is following the same trend as the income levels of the commuters' has also undergone significant changes since 2009.

Table 7

Estimated Fuel and Travel Time Cost per km per Selected Vehicle under Steady and Congested Traffic Flow Conditions on $\mathrm{NH}-2$

\begin{tabular}{|l|c|c|c|}
\hline \multicolumn{1}{|c|}{ Vehicle Type } & $\begin{array}{c}\text { Cost Under Steady State } \\
\text { (in \$ / km) }\end{array}$ & $\begin{array}{c}\text { Cost Under Congested State } \\
\text { (in \$ / km) }\end{array}$ & Percent Change \\
\hline Fuel Cost & \multicolumn{4}{|c|}{} \\
\hline Small Car & $0.07(0.05)$ & 0.09 & 21.9 \\
\hline Big Car & 0.06 & 0.08 & 38.3 \\
\hline Two Wheeler & $0.03(0.02)$ & 0.04 & 120.9 \\
\hline HCV & 0.14 & 0.32 & 129.4 \\
\hline Bus & 0.13 & 0.30 & 135.8 \\
\hline MCV & 0.18 & 0.42 & 54.7 \\
\hline Travel Time Cost & \multicolumn{3}{|l|}{} \\
\hline Small Car & $0.130(0.060)$ & 0.21 & 82.9 \\
\hline Big Car & $0.021(0.019)$ & 0.04 & 42.7 \\
\hline Two Wheeler & 0.004 & 0.01 & 18.7 \\
\hline HCV & $0.740(0.310)$ & 0.88 & 52.7 \\
\hline Bus & 0.010 & 0.01 & $2009)$ \\
\hline MCV
\end{tabular}

Note: Values in parenthesis represent steady state costs determined in IRC: SP-30 (IRC, 2009) 


\section{Conclusions}

In the present study, maiden attempt has been made to identify the need and thus develop the congestion cost equations for specific vehicle types operating on varying widths of multi-lane divided carriageways. The conclusions drawn are given below:

- It is well understood that the travel time cost plays a significant role in economic analysis in addition to the other VOC components. Hence a rational approach has been adopted to evaluate the timerelated congestion cost separately for passenger and goods vehicles. The travel time cost for passenger vehicles is obtained by multiplying the travel time per $\mathrm{km}$ with the value of time of passengers and average occupancy of the vehicles. At the same time, the travel time cost for goods vehicles is obtained by multiplying the travel time per $\mathrm{km}$ with the commodity holding cost of the vehicle. Adopting the above analogy, linear relationship has been established between travel time costs per $\mathrm{km}$ and flow for different road sections.

- The typical parabolic shape curves have been developed between the fuel consumption and journey speed of the petrol driven small cars, diesel driven big cars, two wheelers and two axle trucks. These fuel consumption curves are compared with the updated steady state condition equations recently developed. From this, the optimum speed for petrol driven small cars, diesel driven big cars, two wheelers and two axle trucks are 58 $\mathrm{kmph}, 62 \mathrm{kmph}, 60 \mathrm{kmph}$ and $74 \mathrm{kmph}$ respectively. It is further interesting to note that the fuel consumption under steady and congested conditions would be same for speeds in excess of $55 \mathrm{kmph}$ and above in the case of small cars, 60 $\mathrm{kmph}$ and above in the case of big cars and two axle trucks, and $45 \mathrm{kmph}$ and above for two wheelers.

- Suitable relationships were developed between Time Related Congestion Factors and V/C ratio for cars, two wheelers, buses, LCVs, HCVs and MCVs. The congestion factors increases with increase in traffic flow in this case.

- Typical parabolic curves were developed between the Fuel Related Congestion Factors and Volume-Capacity ratio for petrol driven small cars, diesel driven big cars, two wheelers and two axle trucks. The fuel consumption decreases with increase in $\mathrm{V} / \mathrm{C}$ ratio till vehicle reaches its optimum speed and increases later on.

- The congestion equations developed for the assessment of fuel consumption have been further validated to check for its accuracy and rationality. This is accomplished by developing a goodness of fit plot between the predicted and observed fuel consumption for different vehicle types. The statistical validity of the above equations can be judged from the high values of $\mathrm{R} 2$, significant $t$-value, low standard error of the coefficients and low RMSE for all the vehicle types.

Finally, the suitability of developed congestion cost equations have been demonstrated by taking a real test section and estimated the effect of congestion on fuel and time cost. Hence, it is concluded from the study that the developed congestion cost equations can be applied on any carriageway namely four, six and eight lane divided carriageways in order to estimate the loss in fuel and travel time due to congestion. 


\section{Acknowledgements}

The authors are thankful to the Director, Central Road Research Institute (CRRI), New Delhi, India for granting permission to publish this paper. The staff of CRRI who is also associated in data collection is also highly acknowledged.

\section{References}

BTRE, 2007. Estimating Urban Traffic and Congestion Cost Trendsfor Australian Cities. Bureau of Transport and Regional Economics (BTRE). Department of Transport and Regional Services, Canberra, Australia.

CRRI, 2001. Updation of Road User Cost Data. Final Report Volume-I and II submitted to Ministry of Surface Transport (MOST), Central Road Research Institute (CRRI), New Delhi.

Deepa, C. 2011. Development of Congestion Cost Equations for Multi-Lane Highways. Masters' Thesis, NIT Surathkal, India.

Goodwin, P. 2004. The economic costs of road traffic congestion. Discussion Paper, Rail Freight Group, UK.

Greenwood, I.D. 2003. A new approach to estimate congestion impacts for highway evaluation. University of Auckland, New Zealand.
IRC. 2009. Manual for Economic Evaluation of Highway Projects in India. IRC:SP-30, Indian Roads Congress (IRC), New Delhi.

Kadiyali, L.R. 1992. Study for Updating Road User Cost Data. Final Report submitted to Ministry of Surface Transport (MOST) and Asian Development Bank (ADB), Dr. L.R. Kadiyali \& Associates, New Delhi.

Kumar, S. 2011. Development of Steady State Fuel Consumption Equations for Multi-Lane Highways. Masters' Thesis, NIT Surathkal, India.

Transport Canada. 2006. The Cost of Urban Congestion in Canada. Transport Canada Environmental affairs, Canada.

USDOT. 2009. Assessing the Full Costs of Congestion on Surface Transportation Systems and reducing them through Pricing. Office of Economic and Strategic Analysis, U.S. Department of Transportation, USA.

Velmurugan, S.; Errampalli, M.; Ravinder, K.; Sitaramanjaneyulu, K.; Gangopadhyay, S. 2010. Critical Evaluation of Roadway Capacity of Multi-Lane High Speed Corridors under Heterogeneous Traffic Conditions through Traditional and Microscopic Simulation Models, Journal of Indian Roads Congress, 71(3): 235-264. 